\title{
WSPÓŁCZESNE PROBLEMY MIGRACJI PERSONELU MEDYCZNEGO W POLSCE I W EUROPIE
}

\section{WSTĘP}

Celem niniejszego referatu jest porównanie migracji personelu medycznego, w szczególności lekarzy i pielęgniarek, przed wejściem Polski do Unii Europejskiej oraz po jej akcesji, a także ocena zmian w strukturze siły roboczej w ochronie zdrowia na przestrzeni ostatnich kilku lat. Proces migracji oceniono w oparciu o wyniki badania pilotażowego dotyczącego wpływu poszczególnych czynników psychospołecznych na kształtowanie postaw personelu medycznego i jego zadowolenie z wykonywanej pracy, opracowania statystyczne Ministerstwa Zdrowia, Światowej Organizacji Zdrowia wskazujące liczbę zatrudnionych lekarzy i pielęgniarek oraz uprawnionych do wykonywania zawodu na terenie naszego kraju w latach 2003-2009.

Na skutek akcesji Polski do Unii Europejskiej zaczął narastać problem związany $\mathrm{z}$ rosnącą skalą mobilności pracowników ochrony zdrowia. Zagadnienie migracji personelu medycznego, a w szczególności lekarzy i pielęgniarek, stało się przedmiotem debat politycznych i społecznych. Obecnie migracja wysokiej klasy specjalistów jest zjawiskiem masowym i przyczyną kryzysu kadr medycznych uwarunkowanego systematyczną utratą wykwalifikowanego personelu.

Nie ulega wątpliwości, że sektor ochrony zdrowia cechuje jedna z najwyższych aktywności w zakresie mobilności pracowników. W gałęzi tej zatrudnionych jest ponad sześć milionów pracowników, co powoduje, że ochrona zdrowia stanowi jeden z najbardziej znaczących sektorów w Unii Europejskiej (9,7\% siły roboczej UE). Wydatki na ochronę zdrowia pochłaniają średnio od 7\% do $11 \%$ produktu krajowego brutto krajów członkowskich. W krajach Europy Zachodniej wydatki związane $\mathrm{z}$ rekrutacją i utrzymaniem pracowników ochrony zdrowia stanowią 70\% całego budżetu przeznaczonego na leczenie. 
Do oceny zmieniających się trendów w strukturze zmian zasobów ludzkich w ochronie zdrowia w krajach Unii Europejskiej wykorzystywane są następujące wskaźniki:

- przewidywania - kształtowania i rozwoju w zakresie zasobów ludzkich (aktualnej wiedzy),

- odkrywania - szans i zagrożeń pojawiających się w otoczeniu, między innymi możliwości poszerzania dotychczasowej wiedzy i umiejętności,

- preferencji - migracji pracowników w sektorze usług zdrowotnych ${ }^{1}$.

\section{OCENA ZMIAN W STRUKTURZE SIŁY ROBOCZEJ W OCHRONIE ZDROWIA W EUROPIE NA PRZESTRZENI OSTATNICH 10 LAT}

Fundamentalną rolę w procesie zmian w strukturze zasobów ludzkich w organizacjach ochrony zdrowia odgrywają trendy demograficzne, kształtujące zarazem kierunki zatrudniania w placówkach medycznych. Trwale utrzymujące się w Europie niskie tempo przyrostu naturalnego powoduje poważne konsekwencje zarówno dla całego systemu ochrony zdrowia, jak i osób zatrudnionych w tym sektorze. Prognozy europejskie pokazują, iż populacja w Europie spadnie z 726 milionów (2003 - rok bazowy) do 696 milionów w 2025 roku, co na tle świata obniży liczebność ludności z 11,5\% do 9\%². W obrębie niektórych krajów europejskich ocenia się, że średni wiek populacji wzrośnie z 38,3 lat (1995 - rok bazowy) do 41,8 lat w 2015 roku, co negatywnie wpłynie na dostępność siły roboczej. Wpływ tych niekorzystnych trendów pozostanie nie bez znaczenia dla osób zatrudnionych $w$ organizacjach ochrony zdrowia. Dotychczas spadku zatrudnienia doświadczyły kraje takie, jak: Dania, Islandia, Norwegia, Szwecja i Francja, głównie w grupie pielęgniarek, a przeciętny wiek tej grupy zawodowej w 2002 roku wyniósł 41-45 lat ${ }^{3}$. W Wielkiej Brytanii w 2002 roku jedna na pięć pielęgniarek była w wieku 50 lat lub starszym, a prawie połowa miała około 40 lat ${ }^{4}$. W krajach tych pojawił się problem zmniejszającej się liczby młodego personelu pielęgniarskiego. $\mathrm{Na}$ przestrzeni dziesięciu lat, pomiędzy rokiem 1988 a 1998, liczba pielęgniarek

1 M. J. Garret, An Introduction to National Futures Studies for Policymakers in the Health Sector, „World Health Statistics Quarterly” 1994, 47: 3/4, s. 101-117.

2 Nations United, World Population 2002, United Nations Population Division, Department of Economic and Social Affairs, New York 2003.

3 DREES, Direction de la recherche, des etudes, de l'evaluation et des statistiques, Les acteurs et les structures, La Documentation Francaise, Paris 2002.

4 B. Finlayson, Mind the gap: the extent of the NHS nursing shortage, „British Medical Journal” 2002, 325: 538-541. 
w Wielkiej Brytanii poniżej 30 roku życia spadła z 30\% do 15\% ${ }^{5}$. Podobne trendy demograficzne obserwowane są w innych profesjach medycznych. W 1985 roku $55 \%$ francuskich lekarzy było przed 40 r.ż., a w 2000 roku ich liczba spadła już do jedynie 23\%. Przeprowadzony w Wielkiej Brytanii spis ludności wykazał, że w sektorze ochrony zdrowia było zatrudnionych zaledwie 19\% lekarzy poniżej 40 r.ż., a przeszło $40 \%$ stanowili specjaliści powyżej 50 r.ż., wpływając negatywnie na podaż świadczeń zdrowotnych ${ }^{6}$. Wskazane tendencje sugerują, iż pomimo dużego nacisku na rozwój zasobów ludzkich w medycynie, sytuacja na rynku pracy w ochronie zdrowia w całej Europie będzie generować poważne problemy zarówno dla świadczeniobiorców, jak i świadczeniodawców.

Oprócz dylematu starzejącej się populacji, należy zauważyć, że inne trendy demograficzne będą miały również znaczący wpływ na strukturę siły roboczej w ochronie zdrowia. Zmiany te dotyczą przede wszystkim równowagi płci pracowników medycznych, a także licznych migracji w tym sektorze. W obrębie Unii Europejskiej systematycznie wzrasta liczba kobiet podejmujących pracę w ochronie zdrowia. Ich liczba gwałtownie zwiększyła się z poniżej 40\% w 1970 roku do prawie $70 \% \mathrm{w}$ roku 2000, w przedziale wiekowym 25-49 lat ${ }^{7}$. W europejskich krajach OECD liczba kobiet wykonujących pracę w tym obszarze zwiększyła się przeciętnie z 55\% w 1990 roku do 60\% w 2001 roku$^{8}$. Zachodzące zmiany wyraźnie sugerują, iż w Europie zanikają różnice płci wśród osób podejmujących zatrudnienie, w przyszłości zaś kobiety mogą stanowić główne źródło siły roboczej w ochronie zdrowia. Przyczynę tego stanu najprawdopodobniej stanowią zmiany organizacyjne polegające na uelastycznieniu zatrudnienia. Wiąże się to także $\mathrm{z}$ wprowadzeniem licznych zmian w samym procesie leczenia, w kierunku skracania czasu i kosztów hospitalizacji, a także z implementacją nowych zaawansowanych metod leczenia chorych. Na przestrzeni ostatnich lat system pracy zmieniło $83 \%$ belgijskich pielęgniarek, $75 \%$ brytyjskich pielęgniarek oraz $48 \%$ zatrudnionych w niemieckich szpitalach ${ }^{9}$. Wcześniej problem stanowiła ponadwymiarowa praca personelu medycznego. W badaniach ankietowych przepro-

5 Visiting United Kingdom Central Council for Nursing Midwifery and Health, Annual Report, UKMCC, London 1998.

6 RCP, Census of consultant physicians in the UK, 2001, Data and commentary, Royal College of Physicians, London 2002.

7 Communities, Report of Commission of the European, Report from the Commission to the Council, the European Parliament, the Economic and Social Committee and the Committee of the Regions, Commission of the European Communities, Brussels 2002.

8 OECD Report, OECD employment outlook 2002: statistical annex, Organisation for Economic Co-operation and Development, Paris 2002.

9 R. Verschuren, B. De Groot, S. Nossent, Working conditions in hospitals in the European Union, European Fundation for the Improvement of Living and Working Conditions, Dublin 1995. 
wadzonych w Wielkiej Brytanii w 1999 roku 59\% badanych pielęgniarek skarżyło się na konieczność wykonywania godzin nadliczbowych ${ }^{10}$.

W Polsce jednakże problem ten nadal istnieje. $Z$ przeprowadzonych w 2008 roku badań pilotażowych wynika, że do najistotniejszych czynników utrudniających wykonywanie codziennych obowiązków w grupie pielęgniarek można zaliczyć stres i zmęczenie oraz wypalenie zawodowe.

Obecnie na terenie Unii Europejskiej odchodzi się od form standardowego zatrudniania w kierunku zwiększenia elastyczności przez oferowanie pracy w niepełnym wymiarze godzin, krótkookresowe kontrakty, „pracę na wezwanie” oraz wiele innych form umożliwiających dostosowanie pracy do wymagań i potrzeb pracowników. W Belgii, Danii, Holandii, Szwecji, a także Wielkiej Brytanii ponad $40 \%$ osób zatrudnionych jest w niepełnym wymiarze godzin zarówno w placówkach publicznych, jak i prywatnych ${ }^{11}$. Jedynie cztery kraje europejskie, takie jak: Grecja, Włochy, Portugalia i Hiszpania mają zaledwie 10\% personelu medycznego świadczącego pracę w niepełnym wymiarze godzin.

System ten umożliwia rozwój kadry medycznej przez łączenie kilku prac oraz prywatnej praktyki medycznej z pracą w placówce publicznej. Do tej pory najbardziej rozpowszechniony został w Wielkiej Brytanii i krajach skandynawskich.

\section{ZJAWISKO I PROBLEMY MIGRACJI KADRY MEDYCZNEJ W POLSCE IW EUROPIE}

Kolejnym trendem w zachowaniu pracowników ochrony zdrowia są rosnące migracje, mające miejsce głownie na terenie Europy. Badania wskazują na rosnące tempo migracji międzynarodowych. Liczba migrujących przedstawicieli zawodów medycznych podwoiła się z 75 milionów w 1965 roku do 150 milionów w roku $2000^{12}$. $60 \%$ migracji obejmowało nie tylko samych pracowników ochrony zdrowia, ale również ich rodziny. Według raportu Światowej Organizacji Zdrowia dotyczącego światowego kryzysu kadr medycznych, braki kadrowe, głównie lekarzy i pielęgniarek, szacowane są na około 4,25 mln złotych. Jak wynika z raportu WHO, kryzys kadr medycznych dotyczy większości państw na świecie. Sytuacja

10 D. Robinson, J. Buchan, S. Hayday, On the agenda: changing nurses'careers in 1999, Institute of Employment Studies, Warwick University, Warwick 1999.

${ }_{11}$ M. De Troyer, The hospital sector in Europe, Introductory Report, TUTB-SALTSA Conference, Brussels 2000.

12 World Migration Report 2000, International Organization for Migration, IOM, Geneva 2000. 
ta uwarunkowana jest głównie niewystarczającymi inwestycjami w edukację kadry medycznej, niskimi zarobkami oraz niewłaściwymi warunkami pracy ${ }^{13}$.

Rosnące migracje przyczyniają się do utraty kadry z wysokimi kwalifikacjami i umiejętnościami, kształtując pewne wzorce i typologie zachowań personelu medycznego (tab. 1). Analizując przyczyny migracji personelu medycznego w krajach europejskich, możemy wyróżnić dwa podstawowe typy migracji: permanentne oraz okresowe. Pierwszy typ migracji dotyczy głównie osób młodych, które po ukończeniu studiów medycznych chcą rozpocząć swoją karierę zawodową w krajach zapewniających lepsze warunki finansowe oraz bytowe. Przejściowe migracje związane są najczęściej z chęcią zwiększenia doświadczenia i pozyskiwania nowej wiedzy celem zaimplementowania nowych rozwiązań w kraju macierzystym.

Tabela 1. Typologie migrujących pracowników ochrony zdrowia

\begin{tabular}{|l|l|}
\hline \multicolumn{2}{|c|}{ PERMANENTNE MIGRAcJe } \\
\hline Uwarunkowania ekonomiczne & $\begin{array}{l}\text { - wyższy standard życia } \\
\text { - lepsze warunki bytowe i materialne }\end{array}$ \\
\hline Możliwość kariery zawodowej & $\begin{array}{l}\text { - większe szanse rozwoju zawodowego (kształcenia, podnoszenia kwalifikacji, } \\
\text { awansu) }\end{array}$ \\
\hline Migracja innego członka rodziny & $\begin{array}{l}\text { - nieplanowane przemieszczenia } \\
\text { - rezultat zmiany zatrudnienia małżonka lub partnera }\end{array}$ \\
\hline Praca czasowa, najczęściej wakacyjna & - poprawa sytuacji finansowej rodziny migrującego migracje \\
\hline Prowadzenie badań naukowych & $\begin{array}{l}\text { - pozyskiwanie nowej wiedzy i technologii w celu wykorzystania w kraju macierzy- } \\
\text { stym }\end{array}$ \\
\hline Szkolenia & $\begin{array}{l}\text { - nabywanie lub rozwijanie nowych umiejętności w celu wykorzystania w kraju ma- } \\
\text { cierzystym }\end{array}$ \\
\hline Kontrakty & - możliwość poprawy sytuacji finansowej migrującego \\
\hline
\end{tabular}

Źródło: opracowanie własne na podstawie: C. Dubois, M. McKee, E. Nolte, Human resources for health in Europe, European Observatory on Health Systems and Policies Series, Open University Press, WHO 2006.

W Polsce w przeciągu ostatnich lat mamy do czynienia ze zjawiskiem gwałtownej utraty kadry medycznej zarówno ze środowiska lekarzy, jak i pielęgniarek. Od roku 2003 do $2009^{14}$ w samym województwie mazowieckim liczba zatrudnionych lekarzy spadła kilkukrotnie (rys. 1). Największe niedobory kadry medycznej występują w województwach: lubuskim, opolskim i świętokrzyskim.

13 Raport WHO oraz Ministerstwa Zdrowia, Program monitorowania zjawiska migracji polskich lekarzy, pielegniarek i potożnych po przystąpieniu do Unii Europejskiej, WHO, MZ, 2006-2011.

14 „Biuletyny Statystyczne Ministerstwa Zdrowia”, 2004-2008. 


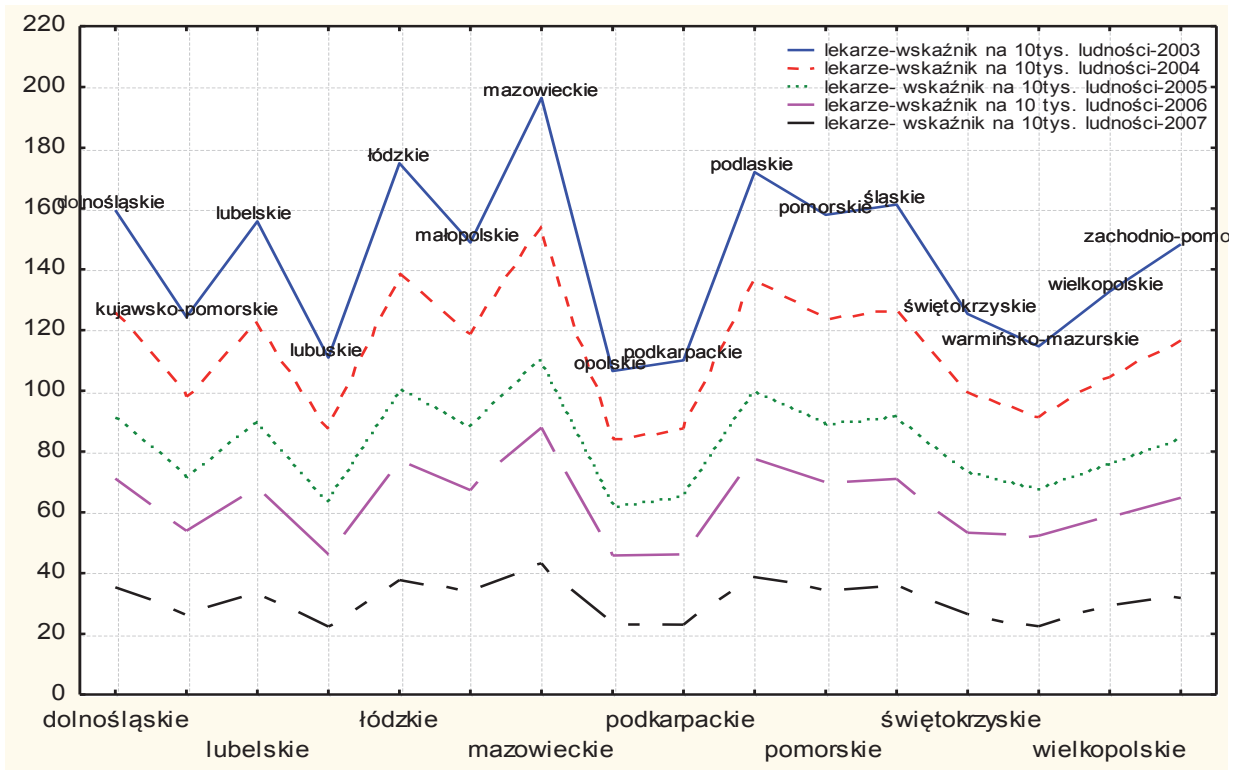

Rysunek 1. Personel lekarski uprawniony do wykonywania zawodu (wg województw) w Polsce w latach 2003-2007 (stan na 31.12 każdego roku) - wskaźnik na 10 tys. ludności

Źródło: opracowanie własne na podstawie: „Biuletyny Statystyczne Ministerstwa Zdrowia”, 2004-2008.

Niekorzystna tendencja spadkowa ujawniła się po roku 2003 i związana była z akcesją Polski do Unii Europejskiej oraz zniesieniem barier formalnoprawnych (między innymi uznawalność dyplomów na terenie innych państw członkowskich) przy zatrudnianiu kadry medycznej na terenie innych państw europejskich. Przeważająca liczba lekarzy ubiegających się o pracę za granicą to osoby ze specjalizacją w zakresie: anestezjologii i intensywnej terapii, chirurgii plastycznej i chirurgii klatki piersiowej oraz medycyny ratunkowej. Na podobną skalę zjawisko migracji do pracy za granicą występuje w grupie pielęgniarek i położnych. Najczęściej podejmują one pracę w opiece długoterminowej oraz domach opieki społecznej.

Kryzys kadr medycznych stanowi problem ogólnoeuropejski. Przyczynami tego zjawiska są w dużym stopniu błędy w zarządzaniu systemami ochrony zdrowia, podejmowanie pracy w sektorze farmaceutycznym zwłaszcza przez personel lekarski, a przede wszystkim komfort pracy oraz niesatysfakcjonujące zarobki. Brak motywacji finansowej i niezadowolenie personelu medycznego w Polsce warunkuje w dużym stopniu decyzje o migracjach kadry medycznej, zwłaszcza w młodszych grupach wiekowych. Od roku 2006 do 2009 liczba wyjeżdżających młodych lekarzy systematycznie się zwiększa w grupie mężczyzn, maleje zaś w grupie kobiet (rys. 2).

Młodego personelu lekarskiego brakuje w województwach: lubuskim, opolskim oraz świętokrzyskim. Liczba lekarzy uprawnionych do wykonywania za- 
wodu na tych terenach jest nawet kilkukrotnie mniejsza niż w województwie mazowieckim czy małopolskim. Zmiana tendencji migracyjnej widoczna jest wraz z wiekiem osób $\mathrm{z}$ wykształceniem medycznym. W grupie wiekowej 55-64 liczba lekarzy z każdym rokiem się zwiększa. Od roku 2006 do 2009 wzrosła o $17 \%$ w grupie kobiet (rys. 4) oraz o blisko $20 \%$ w grupie mężczyzn (rys. 5). Tendencja spadkowa ujawnia się również w grupie wiekowej 35-44 lata w odniesieniu do obu płci (rys. 3).

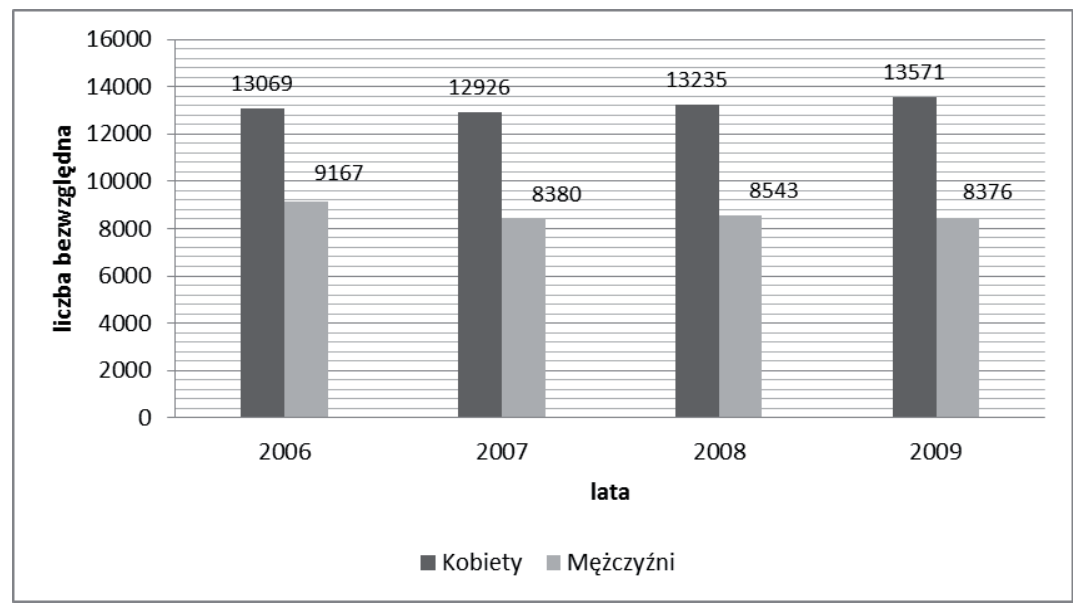

Rysunek 2. Liczba lekarzy uprawnionych do wykonywania zawodu według płci w latach 2006-2009 w grupie wiekowej poniżej 35 roku życia (stan na 31.12)

Źródło: „Biuletyny Statystyczne Ministerstwa Zdrowia” 2006-2010, opracowanie: Centrum Systemów Informacyjnych w Ochronie Zdrowia.

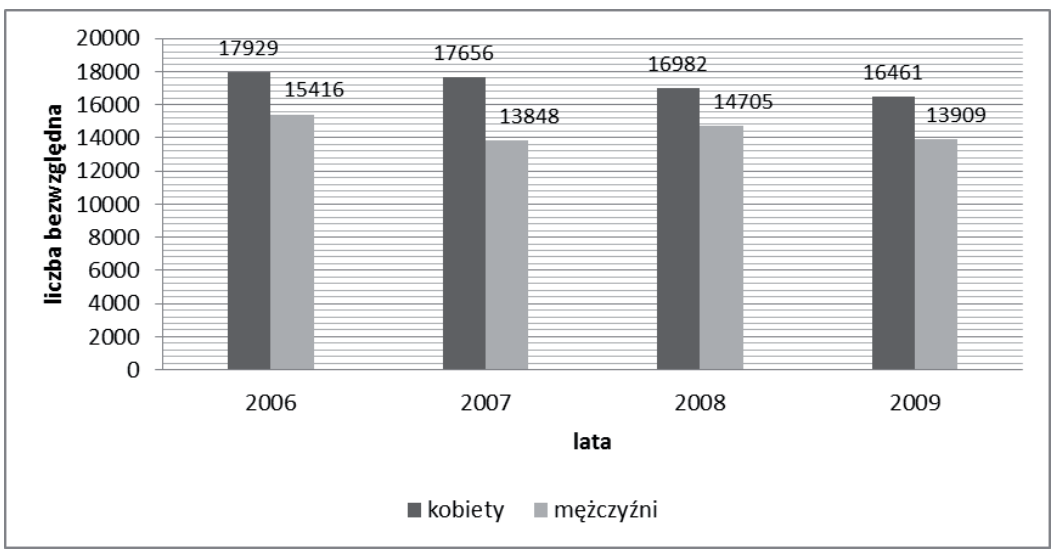

Rysunek 3. Liczba lekarzy uprawnionych do wykonywania zawodu według płci w latach 2006-2009 w grupie wiekowej 35-44 lata (stan na 31.12)

Źródło: „Biuletyny Statystyczne Ministerstwa Zdrowia” 2006-2010, opracowanie: Centrum Systemów Informacyjnych w Ochronie Zdrowia. 


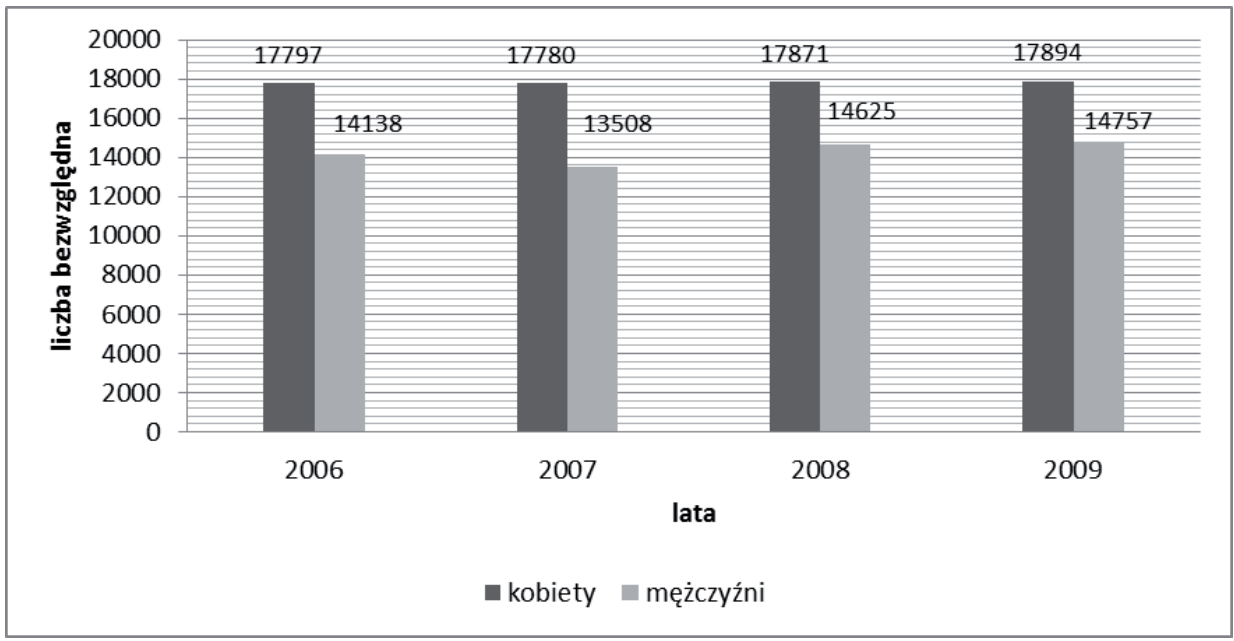

Rysunek 4. Liczba lekarzy uprawnionych do wykonywania zawodu według płci w latach 2006-2009 w grupie wiekowej 45-54 lata (stan na 31.12)

Źródło: „Biuletyny Statystyczne Ministerstwa Zdrowia” 2006-2010, opracowanie: Centrum Systemów Informacyjnych w Ochronie Zdrowia.

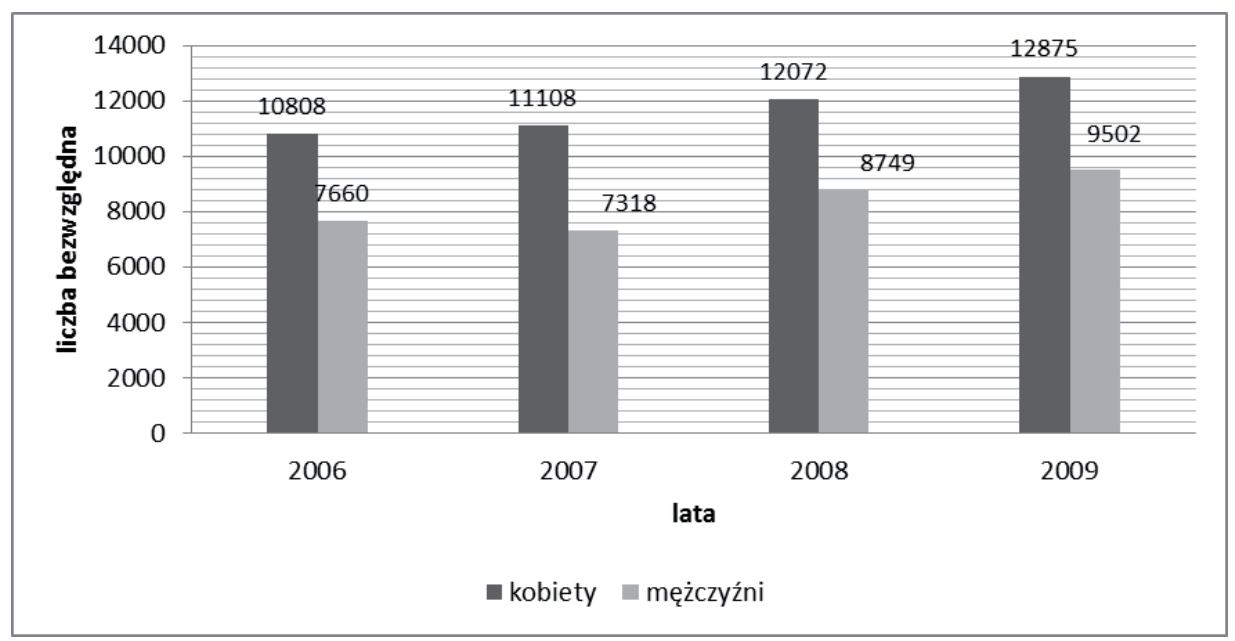

Rysunek 5. Liczba lekarzy uprawnionych do wykonywania zawodu według płci w latach 2006-2009 w grupie wiekowej 55-64 lata (stan na 31.12)

Źródło: „Biuletyny Statystyczne Ministerstwa Zdrowia” 2006-2010, opracowanie: Centrum Systemów Informacyjnych w Ochronie Zdrowia. 


\section{ANALIZA CZYNNIKÓW PSYCHOSPOLECZNYCH WARUNKUJĄCYCH POSTAWY PERSONELU MEDYCZNEGO - WYNIKI BADANIA PILOTAŻOWEGO}

W celu określenia czynników zewnętrznych i wewnętrznych mogących mieć wpływ na postawy personelu medycznego i decyzje o podjęciu pracy $\mathrm{w}$ innym kraju Unii Europejskiej przeprowadzono pilotażowe badanie ankietowe na terenie województwa świętokrzyskiego, którym objęto 66 lekarzy i pielęgniarek spośród losowo wybranych zakładów opieki zdrowotnej. Do przeprowadzenia badania wykorzystano autorski kwestionariusz ankiety dotyczący oceny psychospołecznych problemów związanych z wykonywanym zawodem, składający się z dwóch części: pierwszej - stanowiącej inwentarz socjodemograficzny, umożliwiający zebranie podstawowych danych o respondencie, takich jak: miejsce zamieszkania, dochód na jednego członka rodziny, liczba osób w gospodarstwie domowym, wykształcenie i stan cywilny, drugiej - kwestionariusza ankiety, pozwalającego ocenić cztery kategorie problemów dotyczące relacji z pacjentami, problemów rodzinnych personelu medycznego mogących oddziaływać na pracę zawodową, doświadczeń afektywnych oraz warunków pracy. Pierwsza kategoria: relacje z pacjentem, obejmowała stwierdzenia dotyczące grup problemów związanych z pacjentem, zarówno zachowania samego chorego, jak i jego rodziny. W związku z rosnącymi oczekiwaniami pacjentów co do jakości usług medycznych oraz wpływem środowiska szpitalnego uwzględniono przede wszystkim uwarunkowania emocjonalne, takie jak: pretensje oraz przemoc psychiczna ze strony hospitalizowanych skierowana do lekarzy i pielęgniarek, a także agresywne zachowania rodziny chorych. Kolejna grupa problemów (kategoria: problemy rodzinne) nawiązywała wyłącznie do osobistych dylematów pracowników ochrony zdrowia (między innymi relacje w domu), kłopoty w nawiązywaniu kontaktów z innymi pracownikami placówki medycznej i ich wpływ na codzienną pracę. Ostatnia grupa problemów obejmowała głównie negatywne zachowania uczestników organizacji ochrony zdrowia generujące konflikty interpersonalne, zwiększające rywalizację pomiędzy pracownikami i pogarszające atmosferę $\mathrm{w}$ miejscu pracy. W kwestionariuszu ankiety wykorzystano 5-stopniową skalę Likerta, za pomocą której respondent oceniał, na ile istotny jest dla niego przytoczony problem.

$\mathrm{Z}$ przeprowadzonych badań pilotażowych wynika, że w największym stopniu codzienną pracę lekarzy i pielęgniarek utrudniają problemy związane $z$ doświadczeniami afektywnymi. Największą przyczynę niezadowolenia stanowił stres i zmęczenie. Najczęściej problem ten dotyczył personelu pielęgniarskiego. Lekarze jako przyczynę trudności w pracy wskazywali problemy w postępowaniu z pacjentami, głównie poczucie bezsilności w postępowaniu z chorymi oraz problemy diagnostyczne. W zakresie oddziaływania środowiska pracy nieznaczną 
przeszkodę w wykonywaniu codziennych obowiązków stanowiły konflikty interpersonalne w miejscu pracy (tab. 2).

Tabela 2. Grupy problemów według siły oddziaływania na wykonywaną pracę personelu medycznego - wyniki badania pilotażowego

\begin{tabular}{|c|c|c|c|c|}
\hline Lp. & GrupY Problemów & $\begin{array}{l}\text { ŚREDNIA CAKKOWITA } \\
(N=66)\end{array}$ & LEKarZE & PIEL̨GGNIARKI \\
\hline 1 & Stres i zmęczenie & 3,99 & 3,20 & 4,04 \\
\hline 2 & Problemy psychospołeczne pacjenta & 3,78 & 3,64 & 3,8 \\
\hline 3 & Pretensje ze strony pacjenta & 3,73 & 3,91 & 3,69 \\
\hline 4 & Niewłaściwe zachowanie pacjenta & 3,69 & 3,82 & 3,65 \\
\hline 5 & Poczucie obawy i lęku o pacjenta & 3,60 & 3,90 & 3,30 \\
\hline 6 & Trudny do rozwiązania problem zdrowotny & 3,57 & 3,80 & 3,35 \\
\hline 7 & Poczucie bezsilności w postępowaniu z pacjentem & 3,55 & 3,91 & 3,40 \\
\hline 8 & Wypalenie zawodowe & 3,52 & 3,40 & 3,90 \\
\hline 9 & Depresja związana z wykonywaną pracą & 3,37 & 3,50 & 3,65 \\
\hline 10 & Poczucie empatii & 3,33 & 3,60 & 3,10 \\
\hline 11 & Bezsilność & 3,31 & 3,91 & 4,02 \\
\hline 12 & Świadomość nieprzestrzegania zaleceń przez pacjentów & 3,30 & 3,82 & 3,18 \\
\hline 13 & Agresja ze strony rodziny pacjenta & 3,24 & 3,0 & 3,27 \\
\hline 14 & $\begin{array}{l}\text { Konieczność przekazywania złych informacji pacjentowi } \\
\text { lub jego rodzinie }\end{array}$ & 3,13 & 3,20 & 2,90 \\
\hline 15 & Konflikty interpersonalne w miejscu pracy & 3,09 & 3,18 & 3,09 \\
\hline 16 & Rywalizacja w miejscu pracy & 2,99 & 2,55 & 3,09 \\
\hline 17 & Zła atmosfera w miejscu pracy & 2,96 & 3,09 & 2,95 \\
\hline 18 & Poczucie złości towarzyszące wykonywanej pracy & 2,88 & 2,30 & 3,15 \\
\hline 19 & Przemoc psychiczna ze strony pacjenta & 2,85 & 3,45 & 2,71 \\
\hline 20 & Brak wsparcia ze strony kolegów & 2,84 & 2,73 & 2,87 \\
\hline 21 & Poczucie klęski w postępowaniu z pacjentem & 2,70 & 3,10 & 2,55 \\
\hline 22 & Brak wiary w skuteczność działania & 2,66 & 2,80 & 2,35 \\
\hline 23 & Kłopoty w życiu osobistym personelu medycznego & 2,63 & 2,82 & 2,56 \\
\hline 24 & Brak wsparcia ze strony rodziny pacjenta & 2,63 & 2,91 & 2,55 \\
\hline 25 & Złe relacje w domu & 2,51 & 2,91 & 2,4 \\
\hline 26 & Poczucie posiadania niewystarczającej wiedzy medycznej & 2,36 & 2,70 & 2,10 \\
\hline 27 & Kłopoty w życiu towarzyskim personelu medycznego & 2,28 & 2,73 & 2,16 \\
\hline 28 & Poczucie winy w postępowaniu z pacjentem & 2,16 & 2,64 & 2,04 \\
\hline
\end{tabular}

Objaśnienia: Pyt 1-15: czynniki mające wpływ na pracę personelu medycznego według siły oddziaływania, Pyt 16-28: brak oddziaływania wyżej wymienionych czynników.

Źródło: opracowanie własne. 


\section{ZAKOŃCZENIE}

Zarówno dane statystyczne dotyczące skali zjawiska migracji personelu medycznego, jak i wyniki badań własnych wskazują, że proces ten jest uwarunkowany wieloma czynnikami zarówno finansowymi, jak i związanymi bezpośrednio z warunkami pracy w danym kraju. W wymiarze makroekonomicznym tempo migracji pracowników ochrony zdrowia uzależnione jest od sytuacji gospodarczej oraz politycznej kraju. Głównym jednak bodźcem dla personelu medycznego w Polsce do podjęcia pracy za granicą są niekomfortowe warunki pracy oraz niesatysfakcjonujące zarobki. Wejście Polski do Unii Europejskiej umożliwiło kadrze medycznej nie tylko zdobycie lepiej płatnej pracy, ale również pozyskanie nowych umiejętności w zakresie nowoczesnych technologii medycznych, a także podniesienie kompetencji językowych. Migracja uwarunkowana również zmieniającymi się trendami demograficznymi (starzeniem się społeczeństwa) zwiększa popyt na pracę lekarzy i pielęgniarek w krajach bogatszych stosujących aktywną politykę rekrutacyjną.

Syntetyzując, w Polsce migracja personelu medycznego uwarunkowana w dużej mierze złymi warunkami pracy obniża dostępność do specjalistycznych świadczeń medycznych, zwiększając koszty po stronie pacjentów poprzez konieczność korzystania z odpłatnych usług specjalistów. Jak wynika z raportu „Diagnoza społeczna 2009”, w 2009 roku wzrósł odsetek osób korzystających z usług różnych placówek ochrony zdrowia opłacanych z „własnej kieszeni”. Wśród różnych grup społeczno-ekonomicznych najczęściej z prywatnej opieki medycznej korzystają pracownicy oraz osoby pracujące na własny rachunek, w największym stopniu w województwach mazowieckim oraz dolnośląskim. Na leczenie w niepublicznych zakładach opieki zdrowotnej decydują się głównie osoby bardziej zamożne. Należy jednak przypuszczać, iż głównym czynnikiem warunkującym taki wybór społeczeństwa są nie tylko zarobki, ale przede wszystkim ograniczenie dostępu do specjalistów - zbyt długie terminy oczekiwania na przyjęcie. Sytuacja ta powoduje systematyczny wzrost kosztów po stronie pacjentów.

\section{BIBLIOGRAFIA}

„Biuletyny Statystyczne Ministerstwa Zdrowia”, 2004-2008.

Communities, Report of Commission of the European, Report from the Commission to the Council, the European Parliament, the Economic and Social Committee and the Committee of the Regions, Commission of the European Communities, Brussels 2002.

Czapiński J., Panek T., Raport - Diagnoza spoteczna 2009, Rada Monitoringu Społecznego, Warszawa 2009. 
De Troyer M., The hospital sector in Europe, Introductory Report, TUTB-SALTSA Conference, Brussels 2000.

DREES, Direction de la recherche, des etudes, de l'evaluation et des statistiques, Les acteurs et les structures, La Documentation Francaise, Paris 2002.

Finlayson B., Mind the gap: the extent of the NHS nursing shortage, „British Medical Journal" 2002, 325: 538-541.

Garret M. J., An Introduction to National Futures Studies for Policymakers in the Health Sector, „World Health Statistics Quarterly” 1994, 47: 3/4, s. 101-117.

Nations United, World Population 2002, United Nations Population Division, Department of Economic and Social Affairs, New York 2003.

OECD Report, OECD employment outlook 2002: statistical annex, Organisation for Economic Co-operation and Development, Paris 2002.

Raport WHO oraz Ministerstwa Zdrowia, Program monitorowania zjawiska migracji polskich lekarzy, pielegniarek i potożnych po przystapieniu do Unii Europejskiej, WHO, MZ, 2006-2011.

RCP, Census of consultant physicians in the UK, 2001, Data and commentary, Royal College of Physicians, London 2002.

Robinson D., Buchan J., Hayday S., On the agenda: changing nurses'areers in 1999, Institute of Employment Studies, Warwick University, Warwick 1999.

Verschuren R., De Groot B., Nossent S., Working conditions in hospitals in the European Union, European Fundation for the Improvement of Living and Working Conditions, Dublin 1995.

Visiting United Kingdom Central Council for Nursing Midwifery and Health, Annual Report, UKMCC, London 1998.

World Migration Report 2000, International Organization for Migration, IOM, Geneva 2000.

\section{STRESZCZENIE}

$\mathrm{W}$ artykule zaprezentowano podstawowe problemy związane $\mathrm{z}$ rosnącą migracją personelu medycznego w Polsce i w Europie. Omawiając te zagadnienia, zwrócono uwagę na zmiany w strukturze siły roboczej w ochronie zdrowia na przestrzeni ostatniego dziesięciolecia, a także przebieg procesu migracji kadry medycznej na terenie naszego kraju w oparciu o dane statystyczne Ministerstwa Zdrowia. W artykule podjęto próbę pokazania rezultatów badań pilotażowych dotyczących analizy czynników psychospołecznych kształtujących postawy personelu medycznego w środowisku pracy. 


\section{THE CURRENT PROBLEMS OF THE MIGRATION OF MEDICAL PERSONNEL IN POLAND AND EUROPE}

\section{SUMMARY}

The main aim of this paper was a comparison of the migration of medical personnel, especially doctors and nurses, before and after Polish accession to the European Union. The migration process has been evaluated based on the results of a pilot study and statistics of the Ministry of Health, and the World Health Organization, indicating the number of employed doctor and nurses in our country and Europe in years 2003-2009. 
